\title{
Out of the Shadows: Republican Criminology and the Children of Prisoners
}

\author{
Rebecca Wallis and Susan Dennison
}

\begin{abstract}
The Australian criminal justice system pays little attention to the impact of imprisonment on prisoners' dependent children, even though these children are often very vulnerable. In this article, it is argued that the system can better respond to children of prisoners by adopting Braithwaite and Pettit's theory of republican criminology as a normative framework. Specifically, the relevance of Braithwaite and Pettit's argument that the criminal justice system should have the maximisation of personal dominion as its primary goal is explored, in terms of its application to the children of prisoners. By orienting the criminal justice system towards this goal, it is possible for the needs of children to be viewed as an integral part of the business of criminal justice rather than as secondary or adjunct considerations.
\end{abstract}

\section{INTRODUCTION}

When Jessica and Bradley's house was searched, the children were sent into the backyard to play. ${ }^{1}$ Following the search, both adults were arrested and Jessica was given a few minutes to call her mother to come over and mind the children. Luckily, her mother lived close by and arrived quickly. While Jessica and Bradley were driven away, Jessica's mother helped the children finish breakfast and prepared the older ones for school. Jessica and Bradley did not have a chance to say goodbye to the children, and they were not home again at the end of the school day. Neither parent had been imprisoned before, nor had they previously been separated from their children.

Over the next two weeks, Jessica's mother packed up their house and moved all the children (aged between one and 11) to her house. ${ }^{2}$ She enrolled them at the local school closest to her. Fortunately, although this was a new school, the children already had many friends there. Two weeks later, the children finally received a phone call from their mother. She was being held on remand in a correctional centre about $150 \mathrm{~km}$ from

$1 \quad$ All names used in this article have been changed. The case studies used in this article are drawn from 60 life history interviews with imprisoned mothers conducted in correctional centres in Queensland in 2012-2013. The research was supported by an Australian Postgraduate Award (Industry) as part of Australian Research Council Linkage grant (LP0776296).

2 Some details (such as number of children) have been omitted in order to better preserve anonymity of participants. 
their home town. Their father was also remanded in custody. During this initial phone call, Jessica explains:

[I] just told them that mummy and daddy have gone away for a little bit and that we'll be going to try and get home soon and to just be good for nanny and ask them if they were all right and they said they were fine and yeah, that's it. They said that they'll be good and they'll have fun ...

Jessica's story highlights the way that parental imprisonment can change children's lives. With no warning or preparation, her children lost both parents, moved to a new house with a new carer, changed schools, and had to adapt to new daily routines and expectations. They had been provided with little explanation for all this change, although they were aware that their parents were in prison. They understood that all this change was temporary, but no one could provide a concrete time frame. They had to adapt to their new circumstances as best they could:

I guess [the kids] didn't figure out how long exactly that we would be there for. They must have thought oh, it's not going to be long. Do you know what I mean? ... and at first they were asking me when are you coming home, when are you coming home? I kept telling them I don't know but now they're just like, I think they've gotten used to me not being there and they're getting into their routine but yeah, they still want us to come home but they know they just have to wait.

Jessica and Bradley are accused of serious crimes and it is not unusual for them to both be placed on remand in these circumstances. ${ }^{3}$ They are being dealt with by a criminal justice system that is designed to assess guilt and administer punishment. But, regardless of how justified the system response to Jessica and Bradley's alleged wrongdoing, their children are also affected by it. Children of prisoners present a problematic challenge to the criminal justice system. When a parent is subjected to the system and particularly in circumstances where imprisonment is the outcome, children's lives can be severely affected. Yet, within the system, children have no standing and no real ability to assert their needs. In this way, children are rendered invisible within a system that can have as much impact on them as it does on their parents.

In this article, it is argued that the criminal justice system should accept that it owes some responsibility to the children of prisoners, and the nature of this responsibility is explored. Further, it is argued that the system can better respond to children of prisoners by adopting Braithwaite and Pettit's theory of republican criminology as a framework. ${ }^{4}$ Specifically, the relevance of Braithwaite and Pettit's argument that the criminal

3 Section 16 of the Bail Act 1980 (Qld) sets out the circumstances where a court should refuse bail. The nature and seriousness of the offence and the strength of the evidence against the accused are factors that can be taken into account when deciding whether there is an 'unacceptable risk' of various consequences set out in s 16(1) if the defendant is released on bail.

4 John Braithwaite and Philip Pettit, Not Just Deserts: A Republican Theory of Criminal Justice (Clarendon Press, 1990); John Braithwaite and Philip Pettit, 'Not Just Deserts, Even in Sentencing' (1993) 4(3) Current Issues in Criminal Justice 225. 
justice system should have the maximisation of personal dominion as its primary goal is explored in terms of its application to the children of prisoners. ${ }^{5}$ By orienting the criminal justice system towards this goal, it is possible for the needs of children to be considered as an integral part of the business of criminal justice rather than as secondary or adjunct considerations.

This article begins with an overview of what is known about children of prisoners, focusing on children's pre-imprisonment life contexts, the impact of imprisonment on their developmental systems and long-term consequences of parental imprisonment. The operation of sentencing law is then examined to show how it drives a systemic neglect of children's needs. Finally, a republican vision of criminal justice is examined to demonstrate how the system could more appropriately deal with the children of prisoners while continuing to balance their needs with those of offenders, victims, and the wider community.

\section{Children's Experiences of Parental Imprisonment}

Children of prisoners are not an homogenous group and research into the effects of parental imprisonment on children is still fairly embryonic. Although a broad picture of the circumstances of children is emerging in the international literature, much remains to be done to understand the detail of how risk or protective factors function in a child's developmental system and whether or not these factors are universal across time and place.

\section{A Pre-imprisonment Contexts}

Although some children are enmeshed in supportive, functional and protective environments before and during their parent's imprisonment, many are not. ${ }^{6}$ Many of the families affected by imprisonment are already struggling with poverty, violence, criminality and substance abuse before

$5 \quad$ John Braithwaite and Philip Pettit, Not Just Deserts: A Republican Theory of Criminal Justice (Clarendon Press, 1990) 54.

6 See, eg, Lauren Aaron and Danielle Dallaire, 'Parental Incarceration and Multiple Risk Experiences: Effects on Family Dynamics and Children's Delinquency' (2010) 39(12) Journal of Youth and Adolescence 1471; Danielle Dallaire, 'Children with Incarcerated Mothers: Developmental Outcomes, Special Challenges and Recommendations' (2007) 28(1) Journal of Applied Developmental Psychology 15; Dana DeHart and Sandra Altshuler, 'Violence Exposure among Children of Incarcerated Mothers' (2009) 26(5) Child and Adolescent Social Work Journal 467; Julie Poehlmann, 'Children's Family Environments and Intellectual Outcomes During Maternal Incarceration' (2005) 67(5) Journal of Marriage and Family 1275; Susan Dennison and Holly Smallbone, "You Can't Be Much of Anything from Inside": The Implications of Imprisoned Fathers' Parental Involvement and Generative Opportunities for Children's Wellbeing' (Law in Context Vol 32 at page 61); Christopher Wildeman and Kristen Turney, 'Positive, Negative, or Null? The Effects of Maternal Incarceration on Children's Behavioral Problems' (2014) 51(3) Demography 1041. 
the imprisonment of a parent, making children within these families particularly vulnerable. ${ }^{7}$ The circumstances of a child's life before imprisonment are relevant to their experience of parental imprisonment, and may make them more or less vulnerable to experiencing this change as a negative developmental experience. ${ }^{8}$ In particular, the nature of the relationship between the child and the offending parent is important. Recent research in Australia suggests that many imprisoned fathers live with their children before imprisonment. ${ }^{9}$ This is estimated to be higher for mothers, although precise figures are not currently available, ${ }^{10}$ and many imprisoned mothers are reported to be sole caregivers of their children before their imprisonment. ${ }^{11}$

This is similar to data from the United States. For example, Mumola found that the majority of women prisoners were mothers and that a third of these mothers were sole caregivers before their imprisonment. ${ }^{12}$ The nature of the relationship between parent and child before imprisonment naturally produces different circumstances for children during imprisonment. It may be, for some children, that the imprisonment of a parent offers respite from violence, neglect, and the negative effects of addiction or criminality. For other children, imprisonment robs them of a caring and engaged parent. Similarly, a child who was living solely with her mother and without any other regular family support may be left in a more invidious position than a child who is already in state care with little contact with the offending parent. Nonetheless, even children with adequate care are placed in a new position when they become children of 'prisoners' and this change in status is worth acknowledging. ${ }^{13}$

In addition, the presence of strong support from extended family, siblings, peers, educational institutions and social services may make

$7 \quad$ Ibid.

8 Danielle Dallaire and Laura Wilson, 'The Relation of Exposure to Parental Criminal Activity, Arrest, and Sentencing to Children's Maladjustment' (2010) 19(4) Journal of Child and Family Studies 404.

9 Susan Dennison, Anna Stewart and Kate Freiberg, 'A Prevalence Study of Children with Imprisoned Fathers: Annual and Lifetime Estimates' (2013) 48(3) Australian Journal of Social Issues 339, 350. Dennison found that $48.4 \%$ of fathers surveyed had been living with their children before their imprisonment.

10 For example, preliminary results from the current study indicate that 75 of the 97 mothers surveyed (77.32\%) at three female Correctional Centres in Queensland had their children living with them before imprisonment.

11 Simon Quilty, Michael H Levy, Kirsten Howard, Alex Barratt and Tony Butler, 'Children of Prisoners: A Growing Public Health Problem' (2004) 28 Australian and New Zealand Journal of Public Health 339. Quilty et al found that 57\% of surveyed women were mothers, with higher rates for Aboriginal and Torres Strait Islander women at $79 \%$.

12 CJ Mumola, 'Special Report: Incarcerated Parents and Their Children' (US Department of Justice, Bureau of Justice Statistics, 2000). Mumola found that $65 \%$ of women in State prisons and 59\% of women in federal prisons had dependent children.

13 Julie Poehlmann et al, 'Children's Contact with Their Incarcerated Parents: Research Findings and Recommendations' (2010) 65(6) American Psychologist 575 . 
children less vulnerable to the circumstances of their parent's lives, both before and during imprisonment. ${ }^{14}$ These supports may work, in some cases, to protect a child adequately, or help them navigate through the changes associated with their parent's imprisonment. Where these supports exist, and continue to exist throughout a parent's imprisonment, there may be no particular need for state intervention. This is important to remember, as the responsibility sought from the criminal justice system is to meet the individual needs of children of prisoners, and this necessitates a careful assessment of each individual case rather than a 'one size fits all' approach. For example, in Jessica's case, her children are reported to be well supported by their maternal and paternal grandmothers, as well as by their peers, school and local community. Further state-sponsored intervention or support may not be useful or welcomed in such a case, unless the grandmothers' circumstances change. This may be very different for other families. For example, Maud's young children are being cared for by her extended family in an ad hoc manner while she serves a short sentence, but she is unsure of the precise arrangements that have been made for them:

Interviewer: Since then you haven't had any contact with the kids? You've been writing to them and writing to them, but you haven't heard anything?

Maud: Yeah, I got to speak to them once... this was like about five days after I just arrived here, because I rang my friend up and she - because she lives across the road, she quickly ran over there and said something. But I forgot to get the number off her ... But yeah, my oldest son ... he said, I'm loving it. He said, you can stay a bit longer if you like, because I'm having fun. So he wasn't missing me that much, but the young fellow was crying at the time so, yeah, so he's missing me. But the big fellow's like, yeah, we're having fun, mum. We're going to [this town], we're going to [that town], everywhere. So I was a bit sad, but I was happy that he's having fun.

Facilitator: So you don't really know what's going on with them, because there's nobody really you can call to find out?

Interviewee: Yeah, there's no one.

Facilitator: They haven't written back to you to sort anything - and they'd have to write, wouldn't they, to let you know?

Interviewee: Yeah ...

14 Poehlmann, above n 6 (quality of caregiving during imprisonment); Aaron and Dallaire, above n 6 (child's experience of parental criminality, arrest and sentence, family processes and connections); Virginia Mackintosh, Barbara Myers and Suzanne Kennon, 'Children of Incarcerated Mothers and Their Caregivers: Factors Affecting the Quality of Their Relationship' (2006) 15(5) Journal of Child and Family Studies 581 (child's emotional assets, coping skills and family support); Ande Nesmith and Ebony Ruhland, 'Children of Incarcerated Parents: Challenges and Resiliency, in Their Own Words' (2008) 30(10) Children and Youth Services Review 1119 (child's resilience). 


\section{B Parental Imprisonment and its Effects on Children's Developmental Systems}

The imprisonment of a parent can actively disrupt practical aspects of a child's developmental system. It can drive a number of momentous changes, such as a change in caregiver, ${ }^{15}$ home, ${ }^{16}$ school,${ }^{17}$ and can separate siblings and other family members. ${ }^{18}$ Even in cases where their developmental system is supportive and nurturing, this level of change potentially exposes children to unnecessary risk. The resilience of the developmental system can be tested, and if it fails, there are few options available to support its rebuild. For example, in Jessica's case, the ongoing care provided by her mother is dependent on her mother's continued good health, which is not guaranteed. It would be likely that her numerous children would need to be separated among her relatives if such a circumstance arose. Unless the children then became subject to child protection interventions, little support would be available to the family in dealing with this eventuality. In cases where there are few supports available in a developmental system, it is unlikely that disruption will produce new and positive functional supports for children unless active steps are taken by some person or entity to ensure this. ${ }^{19}$

The age of the child at the time of their parent's imprisonment may also impact on the way that they experience this event. Age dictates the presence or absence of key features within a child's developmental system that can be drawn upon for support, or which may present further risks to the child. For example, a school-aged child will experience imprisonment

15 Studies suggest that many children of imprisoned mothers end up in the care of their grandparents, other relatives, or in State care. See, eg, Ann Farrell, 'Policies for Incarcerated Mothers and Their Families in Australian Corrections' (1998) 31(2) Australian and New Zealand Journal of Criminology 101; Mumola, above n 12; Julie Poehlmann, Rebecca J Shlafer, Elizabeth Maes and Ashley Hanneman, 'Factors Associated with Young Children's Opportunities for Maintaining Family Relationships During Maternal Incarceration' (2008) 57(3) Family Relations 267. In the case of imprisoned fathers, Dennison et al, above $\mathrm{n} 9$, found that more children remain living with their mothers (83.1\%), but nonetheless experienced change in other aspects of their lives.

16 Diane Young and Carrie Jefferson Smith, 'When Moms are Incarcerated: The Needs of Children, Mothers, and Caregivers' (2000) 81(2) Families in Society: The Journal of Contemporary Human Services 130; Mackintosh et al, above n 14.

17 See, eg, Mackintosh et al, above $\mathrm{n} 14$, who found that $36 \%$ of children in that study had changed schools in the past year.

18 Candace Kruttschnitt, 'The Paradox of Women's Imprisonment.' (2010) 139(3) Daedalus 32(11); Mackintosh et al, above n 14; Poehlmann et al, above n 15; Dot Goulding, 'Severed Connections: An Exploration of the Impact of Imprisonment on Women's Familial and Social Connectedness' (Murdoch University Research Centre for Social and Community Research, October 2004)

19 See, eg, Nesmith and Ruhland, above n 14, 1123 who observed that children who were isolated and stigmatised, "on the whole ... were without role models, unable to connect to others like themselves, or to find trustworthy people who would help them feel less marginalized in general'. 
differently to a toddler, not only emotionally or psychologically, ${ }^{20}$ but also because of the way that a school setting may mediate a school-aged child's experience of parental imprisonment.

Moreover, for many children, prison itself becomes a part of their developmental system. The culture of a prison, its security level and physical environment, and the processes it employs to maintain family relationships are therefore important. Navigating the corrections system can be difficult, and the relationship between parent and child can suffer. It can be difficult for children to visit their imprisoned parent as a result of distance, ${ }^{21}$ or because of the inhospitable nature of some visits areas. $^{22}$ Other forms of contact such as telephone calls or letters are also problematic as a result of prison policies (such as time allowances and costs of calls) or because of a lack of capacity of parents and children (eg time, literacy, cost). ${ }^{23}$ Relationships mediated by inhospitable prison contexts can also become emotionally fraught. Children can feel anxious and unsettled as a result of their experience of the prison when visiting parents. $^{24}$

Many of the imprisoned mothers interviewed in this study reported conflicted emotions about maintaining relationships with children while in prison, particularly through visits. Charlotte, for example, was a young woman with a young child. She was being held on remand for a fairly serious offence following a string of more petty convictions. It was her first time in prison. She explained why she did not want visits from her son:

Like, I don't know if I'd be able to stop myself from crying if I spoke to him, and I don't know how he'd react, whether it would upset him even more, do you know what I mean? Like, the whole idea of him coming and visiting me, how do you explain to your son that he can't stay or I can't go home with him or to know since he's been with me every single day, it's just - I don't know how to handle it, really. I don't know what else to do. I don't even know if it's the right thing, not talking to him or anything like that. I just think it's easier.

20 See, eg, Julie Poehlmann, 'Representations of Attachment Relationships in Children of Incarcerated Mothers' (2005) 76(3) Child Development 679.

21 Farrell, above n 15; Goulding, above n 18; Young and Smith, above n 16.

22 Julie Poehlmann, 'An Attachment Perspective on Grandparents Raising Their Very Young Grandchildren: Implications for Intervention and Research' (2003) 24(2) Infant Mental Health Journal 149; Poehlmann, above n 13.

23 Elena Hontoria Tuerk and Ann Booker Loper, 'Contact between Incarcerated Mothers and Their Children: Assessing Parenting Stress' (2006) 43(1) Journal of Offender Rehabilitation 23; Farrell, above n 15; Goulding, above n 18; Dennison and Smallbone, above $\mathrm{n} 6$.

24 See, eg, Danielle Dallaire, Anne Ciccone and Laura Wilson, 'Teachers' Experiences with and Expectations of Children with Incarcerated Parents' (2010) 31(4) Journal of Applied Developmental Psychology 281. Dallaire et al highlight the difficulty children have settling into school the week following a visit with their imprisoned parents. 


\section{Long-term Effects of Parental Imprisonment}

There is a growing body of evidence that suggests that parental imprisonment may be a risk factor for poor developmental outcomes for children, but it is difficult to tease imprisonment out from other risk factors present in the lives of many of these children. ${ }^{25} \mathrm{~A}$ recent meta-analysis demonstrated that parental imprisonment is related to anti-social behaviour, but its contribution to other outcomes such as drug use, educational attainment and mental health is not clearly evident. ${ }^{26} \mathrm{~A}$ study by Murray and Farrington exploring data from the Cambridge Study in Delinquent Development demonstrated that the boys affected by parental incarceration within that cohort were five times more likely to be incarcerated as adults themselves, compared with children who were separated from their parents for other reasons. ${ }^{27}$ Smaller studies suggest that children of prisoners are more likely than other children to have high levels of anxiety and depression, ${ }^{28}$ and high levels of social disadvantage, economic strain, and instability of living arrangements. ${ }^{29}$ Despite the current lack of clarity around evidence, the fact that parental imprisonment is a predictor (even if not causative) of poor outcomes is, in itself, a valuable finding, as it highlights the vulnerability of these children and the need to more carefully evaluate and respond to their support needs.

Although the precise mechanics of these negative outcomes are not well understood, the system itself does appear to play some part in the negative experiences of children. Outcomes for children differ between countries, with some jurisdictions (eg the Netherlands and Sweden) appearing to avoid the negative consequences of imprisonment found

25 Christopher Wildeman and Kristen Turney, 'Positive, Negative, or Null? The Effects of Maternal Incarceration on Children's Behavioral Problems' (2014) 51(3) Demography 1041.

26 Joseph Murray, David P Farrington, and Ivana Sekol, 'Children's Antisocial Behavior, Mental Health, Drug Use, and Educational Performance after Parental Incarceration: A Systematic Review and Meta-Analysis' (2011) 138 Psychological Bulletin 175.

27 Joseph Murray and David P Farrington, 'Parental Imprisonment: Effects on Boys' Antisocial Behaviour and Delinquency Through the Life-course' (2005) 46(12) Journal of Child Psychology and Psychiatry 1269. The Cambridge Study is a longitudinal study of 400 males born in England in the 1950s.

28 Stuart A Kinner, Rosa Alati, Jake M Najman and Gail M Williams, 'Do Paternal Arrest and Imprisonment Lead to Child Behaviour Problems and Substance Use? A Longitudinal Analysis' (2007) 48(11) Journal of Child Psychology and Psychiatry 1148; Joseph Murray and David Farrington, 'Parental Imprisonment: Effects on Boys' Antisocial Behaviour and Delinquency through the Life-Course' (2005) 46(12) Journal of Child Psychology and Psychiatry 1269; Joseph Murray and David P Farrington, 'The Effects of Parental Imprisonment on Children' (2008) 37 Crime and Justice 133.

29 Joseph Murray and David P Farrington, 'Evidence-Based Programs for Children of Prisoners' (2006) 5(4) Criminology and Public Policy 721; Susan D Phillips, Alaattin Erkanli, Gordon P Keeler, E Jane Costello and Adrian Angold, 'Disentangling the Risks: Parent Criminal Justice Involvement and Children's Exposure to Family Risks' (2006) 5(4) Criminology and Public Policy 677. 
in, for example, the United Kingdom. ${ }^{30}$ Although this has not yet been comprehensively tested, Murray et al provide strong arguments to suggest that, at least in the Swedish context, this difference may be explained by the very different societal and system attitudes towards punishment and the resulting differences in criminal justice policies and practices. ${ }^{31}$ They argue that a range of issues may be relevant, such as Sweden's use of shorter prison terms, open prisons, family-friendly prison processes around visits and communication, its strong and protective social welfare system, and its more sympathetic public attitude towards crime and punishment. This suggests that the nature of the criminal justice system intervention itself may operate as a risk or protective factor for children whose parents are subject to that intervention. If the system remains unaware of its potential effect on children, it is unable to ensure that any negative consequences are ameliorated.

There has been a recent increase in attention paid to the long-term and intergenerational effects of imprisonment at a societal level. ${ }^{32}$ This research has been driven by a concern for the consequences of policies of mass incarceration in the United States, but is also applicable to the Australian experience. The over-representation of Aboriginal and Torres Strait Islanders is an entrenched feature of the Australian prison system, and the long-term effects of this over-representation on families and communities are poorly understood. Of concern is a recent study by Dennison et al which demonstrates that children of Aboriginal and Torres Strait Islander men in Queensland are four times more likely than non-Indigenous children to experience paternal imprisonment in their lifetime. ${ }^{33}$ If parental imprisonment negatively affects these children's development by, for example, contributing to poor mental health and increased anti-social behaviour, over time this will contribute to a gradual worsening of life outcomes for an already vulnerable section of society. This places further impetus on the criminal justice system to consider the needs of children of prisoners in order to ensure an equitable and healthy society in the long term.

$30 \quad$ See, eg, ibid; S Besemer, V Van der Geest, J Murray, CCJH Bijleveld and DP Farrington, 'The Relationship between Parental Imprisonment and Offspring Offending in England and the Netherlands' (2011) 51(2) British Journal of Criminology 413; Joseph Murray, Carl-Gunnar Janson and David Farrington, 'Crime in Adult Offspring of Prisoners. A Cross-National Comparison of Two Longitudinal Samples' (2007) 34(1) Criminal Justice and Behavior 133.

31 Ibid. For an extended discussion of jurisdictional difference in criminal justice culture, see, eg, John Pratt and Anna Eriksson Contrasts in Punishment: An Explanation of Anglophone Excess and Nordic Exceptionalism (Routledge, 2012).

32 See, eg, Todd Clear, Imprisoning Communities: How Mass Incarceration Makes Disadvantaged Neighborhoods Worse (Oxford University Press, 2007); Todd R Clear, Dina R Rose, Elin Waring and Kristen Scully' 'Coercive Mobility and Crime: A Preliminary Examination of Concentrated Incarceration and Social Disorganization' (2003) 20 Justice Quarterly 33; Sara Wakefield and Christopher $\mathrm{J}$ Wildeman, Children of the Prison Boom: Mass Incarceration and the Future of American Inequality (Oxford University Press, 2014). 


\section{Sentencing LaW and Children of Prisoners}

The circumstances of children, the consequences for them, and the longterm impacts on the children and on society at large, all suggest that there is a need to consider systemic responses to these children to support them through the criminal justice system process (including imprisonment), not just for the sake of each individual child, but for the good of society. This requires the system to take children into account in some way. Currently, there exist few direct avenues for children's needs to be considered, and instead, interventions rely on ad hoc decision-making by relevant parties at point of arrest, trial, sentence and punishment.

An examination of sentencing law provides the central explanation for why police agencies, legal officers and other key institutions within the Australian criminal justice system find it so difficult to systemically consider the needs of children of offenders. The Australian legal system, like many other western democratic systems, has traditionally placed little emphasis on the effects of imprisonment on an offender's family when determining sentence. A court may only impose a sentence on an individual to achieve a particular purpose, such as 'just deserts' punishment, rehabilitation, specific and general deterrence, community denunciation and community protection. ${ }^{34}$ The focus is on establishing a sentence that best fits the individual offender and his or her specific offence. The purposes of punishment listed here reflect the system's desire to balance the interests of the offender against the interests of the community (represented by the state), but the individual offender always remains the central figure in this process. Community interests are framed narrowly (restricted to denunciation and protection), and third party interests, such as those of victims and offenders' children, are afforded little attention. As a result, the impact of punishment on family is a factor of limited relevance at sentence.

In some Australian jurisdictions, the impact of punishment on family is included in legislation as an issue that can be taken into account at sentence. ${ }^{35}$ For example, the Crimes Act 1914 (Cth), s 16A(2)(p) allows the court to consider 'the probable effect that any sentence or order under consideration would have on any of the person's family or dependants'. Yet, even where it is acknowledged as a potential factor to be considered, little weight can usually be placed on this factor. Exceptional circumstances are required ${ }^{36}$ The position of children is summarised clearly in the following statement in the Victorian Supreme Court case of Polterman: ${ }^{37}$

34 See, eg s 9(1) Penalties and Sentences Act 1992 (Qld).

35 See, eg, Crimes Act 1914 (Cth), s 16A(2)(p); Criminal Law (Sentencing) Act 1988 (SA) (s 10(1)(n)).

36 See, eg $R v$ D'Arrigo; Ex parte A-G (Qld) [2004] QCA 399 (De Jersey CJ) for a discussion of exceptional circumstance. See also Richard G Fox and Arie Freiberg, Sentencing: State and Federal Law in Victoria (Oxford University Press, 2nd ed, 1999).

37 Polterman, (unreported, Full Supreme Court of Victoria, 2 August 1974), cited in Richard G Fox and Arie Freiberg, Sentencing: State and Federal Law in Victoria 
[w] hen one appeals for mercy on the grounds of hardship to a wife or family that the accused ought to have had regard to that before embarking on a life of crime, and the Court cannot be blamed because it deals with an accused on the merits having regard to the gravity of the offence, the past circumstances, and so on. The Court is not so inhuman as not to be very sorry for those placed in the position of this wife and child because of the criminal activities of the husband, but our task it [sic] not to yield to pleas based on sentiment or emotion. ${ }^{38}$

In Queensland, there is no specific section in legislation that allows for the position of dependents to be considered, but the Penalties and Sentences Act 1992 s 9(2)(q) allows 'any other relevant consideration' to be taken into account when determining punishment. This has been interpreted to include the impact of the sentence on any dependents, ${ }^{39}$ but again, case law has established that this consideration should only be afforded significant weight in exceptional circumstances. ${ }^{40}$ Instead, a retributive or 'just deserts' model of justice is clearly prioritised, especially in serious cases. This is articulated by Chief Justice De Jersey in D'Arrigo; Ex parte $A-G(Q l d)^{41}$ as follows:

The balance of authority supports the view that while hardship to third parties because of the imprisonment of a family member may, if rarely, be a relevant consideration, it must not overwhelm others such as the need for deterrence, denunciation and punishment.

The law appears to reflect a classical construction of offending as an expression of rational choice, which means that the offender, not the criminal justice system, is solely responsible for any negative consequences of punishment for dependents. This creates a kind of blindness in the legal system to the secondary effects of punishment for families and communities. For example, the mercy referred to in Polterman can be interpreted as mercy requested by and for the primary benefit of the offender in order that his or her dependents will not suffer the consequences of the offender's wrongdoing. Of course, the benefit of mercy here would flow to the dependents, but they are not the primary beneficiaries of this act of mercy. If considered at all, the effects of parental imprisonment on children appear to be justified as unfortunate but inevitable consequences of a parent's wrongdoing. Responsibility is placed back on the offending parents, and little attention is paid to the contribution made by the state intervention itself. This is problematic because, unlike their parents, children of prisoners have committed no crime and there is no proper justification for the impact of parental imprisonment on them. In addition, placing responsibility on an offending parent to buffer and protect their children from the consequences of their actions can leave children at risk;

(Oxford University Press, 2nd ed, 1999). See also the discussion in Richard G Fox, 'When Justice Sheds a Tear: The Place of Mercy in Sentencing' (1999) 25(1) Monash University Law Review 1.

Ibid.

39 See, eg, $R v$ Chong; Ex parte A-G (Qld) [2008] QCA 22.

$40 \quad R$ v D’Arrigo; Ex parte A-G (Qld) [2004] QCA 399 (De Jersey CJ).

41 Ibid. 
and many parents are not capable or willing to act protectively in this manner. Imprisonment also makes it practically difficult for parents to act on their children's behalf, and thus the state intervention creates a barrier for parents' active and positive engagement with their children. It can be almost impossible for imprisoned parents to overcome institutional barriers. ${ }^{42}$ Importantly, if little attention is paid to the role of the state, it becomes difficult to argue for positive innovations within the criminal justice system that might better support the children of prisoners.

The South African case of $S v M^{43}$ provides a marked contrast to the Australian position. In that case, a consideration of the best interests of the child led the court to determine that a non-custodial penalty was more appropriate for the mother. In doing so, the children's needs were considered first and independently from the penalty due to the offender. The appropriate penalty was then formulated in keeping with the children's needs. The centrality of children in the criminal justice process concerning their mother is best summarised in the following extract from Justice Sachs' judgment:

No constitutional injunction can in and of itself isolate children from the shocks and perils of harsh family and neighbourhood environments. What the law can do is create conditions to protect children from abuse and maximise opportunities for them to lead productive and happy lives. Thus, even if the State cannot itself repair disrupted family life, it can create positive conditions for repair to take place, and diligently seek wherever possible to avoid conduct of its agencies which may have the effect of placing children in peril. It follows that section 28 requires the law to make best efforts to avoid, where possible, any breakdown of family life or parental care that may threaten to put children at increased risk. Similarly, in situations where rupture of the family becomes inevitable, the State is obliged to minimise the consequent negative effect on children as far as it can. ${ }^{44}$

In the South African constitution, section 28(2) provides that '[a] child's best interests are of paramount importance in every matter concerning the child' 45 and it was this constitutional imperative that drove such a decision. Nothing similar exists to prioritise children in Australia, except for the obligations arising from Australia's status as a signatory to the United Nations Convention on the Rights of the Child (CROC). ${ }^{46}$

The position of children in sentencing law in Australia has repercussions throughout the practical operation of the system. For example, a defence lawyer is unlikely to be prompted by the law itself to ask about children when preparing a client's defence or plea in mitigation, and may

$42 \quad$ See Dennison, above $\mathrm{n} 6$.

$43 S v M(2008) 3$ SA 232, (Sachs J) (Constitutional Court).

44 Ibid, [20].

45 Constitution of the Republic of South Africa Act 1996 (South Africa).

46 United Nations Convention on the Rights of the Child (CROC) (1989). Various Australian cases have referenced CROC in arriving at appropriate sentences for parents on dependent children, (see, eg, $R v$ Chong; Ex parte A-G (Qld) [2008] QCA 22 (Atkinson J)), but these cases have first needed to pass the test of exceptionalism outlined in $R v$ D'Arrigo; Ex parte A-G (Qld) [2004] QCA 399 (De Jersey CJ). 
therefore never come to hear about children's needs. If the matter is not presented in court, a judge has little opportunity to consider the issues, and in fact, has only a very limited authority to do so anyway as part of sentence. As a consequence, children may not form any part of a judge's sentencing remarks, and their existence may not become obvious even during the administration of a sentence unless prison authorities actively ask about their circumstances. In the absence of a systemic response to children of prisoners, decision-makers within the criminal justice system are free to choose from a number of different responses.

This is highlighted by the variation in experiences reported by participants in the current study. Participants in the current study reported a range of different experiences with police, lawyers, judges, and child protection workers (where relevant) in relation to their children. For example, in some cases, women reported that lawyers took care to ask about arrangements for the children and encouraged them to make appropriate plans. Other women's experiences are echoed in this comment from Pauline, who has two children and is serving a two-year sentence: 'No. Weren't interested. You're paying them, they don't give a shit about the rest of your life'.

Some women praised the care taken by police, or child protection workers, or prison officers, which seemed to be beyond the clear parameters of their jobs. For example, Fiona was held in the watch house for five days awaiting transfer to the correctional centre to commence her lengthy term of imprisonment. She had not been expecting a prison sentence and so her children were not well prepared for her absence. The actions of police officers at the watch house allowed her to keep in touch with an important event in her teenage daughter's life:

The police officers were wonderful. Because ... I just asked - I said I know I can't ring. But can you just ring and see how the day's gone? He went, sure. He came back 20 minutes later and he goes, she did great. Your husband's doing well. He said to give you his love, blah, blah, blah, blah. That was really good. Then when I spoke more to my husband, about that phone call, he said the police officer was great. He said, I spoke to him for about 20 minutes. He said he was absolutely wonderful.

On the other hand, Charlotte's experience with police when she was arrested was not as positive.

They gave me a choice; either my son could come with me and he goes to $\mathrm{DOCS}^{47}$ or I could leave him there with one of my friends. Luckily my best friend was there, so I had no worries. He's got kids of his own, so that was okay, but it's still the fact that it's like, my son didn't know what was happening; it's never happened before. They either give you a choice of DOCS getting involved or you just leave him with a friend. They don't know who my friends were or anything like that.

$47 \quad$ The Department of Communities, Child Safety and Disability Services (Queensland). This department is responsible for child protection matters. 
Many commentators have indicated that there is a clear role for agency intervention for children of parents within the criminal justice system. ${ }^{48}$ Such an agency (government or non-government) would ensure that children are supported through the court process, and that their needs are assessed and further interventions are undertaken as required throughout the term of their parent's imprisonment. However, to understand why solutions like this are not uniformly supported and implemented, there is a need to think much more deeply about the theoretical underpinnings of the criminal justice system. If children are to be more visible and better supported within the system, the system needs to be oriented towards broader social goals.

\section{The Challenge: Freedom, 'Dominion' and the ChILDREN OF PRISONERS}

The situation of children of prisoners presents an excellent test of the proper foundations and purpose of a criminal justice system. The challenge posed by children of prisoners is this: what is the responsibility of the criminal justice system to ensure that its operation/intervention (proper with respect to an offender) does not harm or contribute to harm to an innocent and vulnerable third party? Moreover, what, if any, obligation does it owe to each child, and to a future society, to maximise the developmental potential of these children? An exploration of these questions tests a system that is typically concerned about the proper response to an offender, or at most, to a crime event.

The first question is a narrow one. It asks whether or not the criminal justice system has any responsibility to children for the consequences of its own intervention. Certainly, case law indicates the reluctance of the criminal justice system to assume responsibility for children. Take, for instance, Chief Justice de Jersey's statements in $R v$ D'Arrigo; Ex parte $A-G$ (Qld) regarding the relevance of the existence of dependent children at sentence. ${ }^{49} \mathrm{He}$ states that children are not a relevant consideration except in 'exceptional or extreme circumstances'. Even then, this 'must not overwhelm other [considerations] such as the need for deterrence, denunciation and punishment'. This is followed by an important indication that the system prefers to locate responsibility elsewhere: 'It is not as if the child would be left without care. Care will be provided in the usual way through the Department ... ${ }^{, 50}$

48 See, eg, Anti-Discrimination Commission Queensland, 'Women in Prison' (Anti-Discrimination Commission Queensland, 2006); Flat Out and Victorian Association for the Care and Resettlement of Offenders, 'Children: Unintended Victims of Legal Process - a Review of Policies and Legislation Affecting Children with Incarcerated Parents' (June 2006); NSW Standing Commission on Social Issues, 'A Report into Children of Imprisoned Parents' (12, Parliament of New South Wales Legislative Council, July 1997).

49 [2004] QCA 399.

50 Ibid. 
In this way, the criminal justice system's approach to children is that their situation is best left to other areas of social welfare. However, this approach means that there is no reliable process that ensures social welfare services will be triggered for children if needed. There are some cogent reasons why the criminal justice system is not the appropriate place to assess and respond to the specific needs of children of prisoners. In its current form, it is not a system designed to consider issues of child welfare. At a practical level, this means that it lacks the appropriate infrastructure and staff to provide nuanced support. At a deeper level, a criminal justice response to the needs of children of prisoners risks results such as inappropriate net widening and heavy-handed state intervention. If, however, the system does not recognise the existence of children of prisoners or acknowledge that its actions towards parents can have significant collateral negative consequences on children, the opportunity for the system to play a limited but essential part in recognising and referring children to appropriate support is lost. A failure to undertake this limited role can mean that there is no safeguard in place to prevent the criminal justice system's actions towards the parent from harming, or contributing towards harm to his or her children. There is no certainty that social welfare services will be notified of the need to support children, except perhaps for obvious child protection matters. For these reasons, the criminal justice system should accept some limited responsibility for children.

The second question posed above is more controversial. It asks whether or not the criminal justice system owes a broader duty to children of prisoners. It questions the criminal justice system's responsibility not only for the consequences of the criminal justice system intervention per se, but also towards maximising a child's healthy development more holistically. Braithwaite and Pettit's republican thesis allows us to explore the role of the criminal justice system with respect to the children of prisoners from this broader perspective, and articulates the basis for why the criminal justice system should act protectively towards these children.

Braithwaite and Pettit argue that a republican vision of liberty has 'personal dominion' as its dominant goal, and that the state ought to play an important and active role in ensuring dominion. ${ }^{51}$ They argue that historically, within republican theories:

freedom ... was conceptualised as the social status enjoyed by someone... so protected by the law and culture of his community that he does not have to depend for the enjoyment of independent choice on the grace or favour or mercy of another. ${ }^{52}$

Thus, to enjoy 'personal dominion', Braithwaite and Pettit argue that it is not enough for a person to be free from interference..$^{53}$ Rather, they must

$51 \quad$ Braithwaite and Pettit, above n 4, 226.

52 Ibid.

53 Braithwaite and Pettit, above n 4, 227 explain this as the dominant 19th century conception of 'negative liberty'. See also, Simon Bronitt and George Williams, 'Political Freedom as an Outlaw: Republican Theory and Political Protest' (1996) 
also 'enjoy the security and status of being protected against possible interference'. ${ }^{54}$ Liberty must be actively supported, not simply left to chance. From this theoretical perspective, the proper role of the state is to use law in a way that upholds the freedom of its citizens and actively protects them from interference. Moreover, citizens must be in a position to enjoy freedom because of their status as 'citizens'. Braithwaite and Pettit explain:

Citizens cannot enjoy this liberty as anti-power, this resilient liberty, if they are unable effectively to invoke certain rights or if they live in a poverty that leaves them vulnerable to the powerful. ${ }^{55}$

In the context of the criminal justice system, Braithwaite and Pettit argue that a 'just deserts' model of justice should be rejected. Instead, the goal of maximising personal dominion should be applied to all citizens affected, including victims, offenders, and other stakeholders such as the children of prisoners. A criminal justice intervention that has this goal at its core would recognise that a crime event has impacted on a victim's enjoyment of personal dominion, and would take steps to redress the wrong that has been done to them. ${ }^{56}$ State intervention is fundamental because it signals to the broader community, as well as the victim, that personal dominion is always actively supported by the state. At the same time, this response need not take a form that crushes the personal dominion of the offender; in fact, such a response would stand at odds with a republican agenda. To the full extent possible, actions taken against an offender should be congruent with the maintenance of their dominion. ${ }^{57}$ The appropriate way to achieve these ends with respect to victims, offenders, and the community more broadly has been developed in the restorative justice literature, which is compatible with a republican agenda. ${ }^{58}$

It may be that an offending parent has, by their criminal actions or other behaviour, impacted on their child's enjoyment (and prospects for the enjoyment) of freedom. ${ }^{59}$ If this is the case, a criminal justice system oriented towards a republican goal would recognise its duty to support the restoration of that child's personal dominion, even if the criminal justice system intervention itself has no adverse impact on the child. This is the position reflected in Justice Sachs' comments in $S v M$ where he states that 'the law can ... create conditions to protect children from

18(2) Adelaide Law Review 286; Simon Bronitt and Declan Roche, 'Between Rhetoric and Reality: Sociolegal and Republican Perspectives on Entrapment' (2000) 4 International Journal of Evidence and Proof 77.

54 Braithwaite and Pettit, above n 4, 227.

55 John Braithwaite and Philip Pettit, 'Republican Criminology and Victim Advocacy' (1994) 28(4) Law and Society Review 765, 766.

56 See, eg, ibid; Braithwaite and Pettit, above n 4.

57 See, eg, Braithwaite and Pettit, above $\mathrm{n} 4$ and above $\mathrm{n} 55$.

58 See, eg, John Braithwaite, Crime, Shame and Reintegration (Cambridge University Press, 1989); Eugene McLaughlin, Ross Fergusson, Gordon Hughes and Louise Westmarland (eds), Restorative Justice: Critical Issues (The Open University, 2003).

59 Such as behaviour driven by alcohol or drug addiction or violence. 
abuse and maximise opportunities for them to lead productive and happy lives'. ${ }^{60}$ Currently however, because sentencing has a narrow and individualised focus, children are commonly tied to the offender and are (at best) constructed as purposeful objects within the sentencing process. As purposeful objects, they can be used as leverage against the offender as either objects relevant to achieving specific or general deterrence, or as a part of a rehabilitative agenda, for example - but are not seen as individuals in their own right. At worst, they can be left out of the process altogether if they serve no purpose. A republican theory of criminal justice avoids this by asserting that every stakeholder (including both the victim and a prisoner's child) is equally worthy to enjoy full dominion. Thus, there is a clear responsibility on the state to support this, particularly given the vulnerability of these children and their inability to assert their dominion on their own behalf.

The evidence suggests that there are times, however, when the criminal justice system intervention itself impacts on the child's enjoyment of personal dominion and this is particularly problematic. A republican goal cannot be achieved for one citizen at the expense of another; a response intended to rebuild the dominion of a victim cannot be realised by taking something away from an offender's child who is not culpable for the harm caused by his or her parent. It is justified to take action against an offender (including, perhaps, incarceration) ${ }^{61}$ in order to redress the wrong done to a victim, but a republican goal would require that this response be crafted in a way that simultaneously supports his or her children. This requires consideration of both innovative responses to crime and the development of specific and well-resourced support services for children.

Braithwaite and Pettit have explored the features of a criminal justice system oriented towards a republican goal in some depth, ${ }^{62}$ with a specific focus on how such a system would operate with respect to a victim and an offender. They list the following seven features as key to their theory: its republican goal of maximizing personal dominion (explained above); its comprehensive nature; consequentialist orientation; its rights and limits respecting nature; its tendency towards parsimony, and its practical application. ${ }^{63}$ Each of these features suggests a system that is able to embrace the needs of children of prisoners as part of its operation, as demonstrated if each feature is examined in turn.

Braithwaite and Pettit explain that their theory is comprehensive as it 'supplies a basis for handling the main questions of criminal justice policy', ${ }^{64}$ which can be equally applied at any point within this system from police interaction to sentence administration. The driving point of consideration is whether or not the goal of maximising dominion is

$\overline{60 S v M(2008)} 3$ SA 232 (Sachs J) (Constitutional Court).

61 Provided the action was taken in a manner justified and underpinned by a republican framework as described by Braithwaite and Pettit, above n 4 .

62 Braithwaite and Pettit, above n 4.

63 Ibid, 202.

64 Ibid. 
achieved by the actions of the system at any point. The comprehensive vision offered by the theory ensures that initiatives taken to appropriately incorporate children into criminal justice processes are not simply bolted on to the existing system. Instead, children's needs would be integrated into the system from the outset, making it harder for them to be ignored or cut off over time. It also makes it more difficult for agencies to deny or displace responsibility to other agencies; each component of the system will have at least some responsibility toward ensuring the dominion of children. If the cohesive goal offered by Braithwaite and Pettit's vision of republican criminology was adopted by law makers, government institutions and social welfare services as a normative standard at all stages of the criminal justice process, this would drive the development of, at least, comprehensive and integrated policies towards children at each point. At best, it would also prompt changes to law and the development of more innovative sentencing options that are better suited to the maximization of dominion of all stakeholders.

The consequential orientation of the theory allows the children's immediate and long-term needs to be considered and addressed, as it is concerned with evaluating 'the criminal justice system by the consequences it promotes, not by the constraints it satisfies'. ${ }^{65}$ In this way, the criminal justice system's greater goal is the contribution it makes to a strong and healthy society. This allows the system to consider the situation of prisoners' children in general, rather than be limited to an examination of the impact of the criminal justice system intervention at hand. Currently, it is possible for the criminal justice system to absolve itself of responsibility for children by claiming that the children were already in difficult circumstances and the criminal justice system will have no compounding effect on these circumstances; that they are therefore a child welfare issue rather than a criminal justice system concern. ${ }^{66}$ A consequential orientation, driven by a republican goal, instead directs consideration to the long-term and intergenerational effects of imprisonment for children, particularly if personal dominion is to be embedded and supported within society across generations.

Importantly, the comprehensive nature of the theory (described above), coupled with its consequential orientation, contextualizes the criminal justice system within a broader social system. A fully realised republic would require a more cohesive connection between the criminal justice system and other state and social services. The criminal justice system may not be required to take steps to assess or address the needs of children, but it at least places an impetus on the system to enquire about the situation of children and to refer as appropriate. This would then also require a strong social service sector that is appropriately

65 Ibid

66 See, eg, $R$ v D'Arrigo; Ex parte A-G (Qld) [2004] QCA 399 (De Jersey CJ). 
resourced to meet the needs of children referred to it. ${ }^{67}$ The ability of both the state and society to work together to respond to these children in a timely manner supports each child's healthy development, but may also prevent their interference in others' personal dominion in the future. For example, Murray et al highlighted the integrated relationship between criminal justice system philosophies, prison environments and policies, and broader social welfare systems in Sweden as a likely explanation for the lack of adverse effects caused by parental imprisonment for Swedish children compared to English children. ${ }^{68}$ An integrated and comprehensive republican system may be more capable of dealing holistically with the needs of and challenges posed by a family such as Sally's:

Since I've come in here my boy's started using speed, my oldest boy's started using. My other boy he just shoplifts all the time just to get brand name clothes. My oldest boy goes to court today and they might lock him up. He's 17 now and he's been on probation but hasn't been reporting apparently. My other boy's in juvie and he's not to go to mum's because he attacked dad so he's at my sister's. So it's all fallen apart since I've been in here.

Importantly, Braithwaite and Pettit emphasise that their theory is both rights-respecting and limits-respecting. ${ }^{69}$ These aspects of the theory ensure that the consequential nature does not take on a more capricious form, where the ends justify the means. These features, together with the concept of parsimony (explained as 'the presumption in favour of less intervention rather than more' ${ }^{\prime}$ ), are key to ensuring that the needs of the children of offenders, offenders themselves, and of victims, are properly balanced in a form that is meaningful and procedurally fair. It follows that any state intervention in the lives of children could only be justified if it was clearly required as a support to maximise the children's personal dominion, and could not be arbitrarily invasive or be used as another way of interfering with their freedom. Such an approach would go some way towards allaying the fears of families involved in the criminal justice system who expressed concern at their children being targeted for child protection intervention. Charlotte's reluctance to involve the Department of Communities in her child's care is an example of this reticence. Instead, a broad range of services is required that would provide the level and type of support needed by each individual child on a case by case basis. Charlotte's child may not require an intensive assessment or intervention; rather, a simple check to ensure that the temporary caregiver is appropriate and adequately resourced may be sufficient. The requirement that a republican model is rights-respecting and limits-respecting provides a

67 This could build on the strengths of services already in place such as Sisters Inside (Qld), Shine for Kids (NSW and Vic), or Good Beginnings (WA) which already provide some support for children of prisoners with little funding.

68 Joseph Murray, Carl-Gunnar Janson and David Farrington, 'Crime in Adult Offspring of Prisoners. A Cross-National Comparison of Two Longitudinal Samples' (2007) 34(1) Criminal Justice and Behavior 133.

69 Braithwaite and Pettit, above n 4, 202-203.

70 Ibid, 203. 
strong justification for a support service for children within the criminal justice system, and also requires the development of a robust framework around how services should be delivered within and beyond the criminal justice system.

Finally, Braithwaite and Pettit argue that their theory is practical, and is able to be implemented incrementally if the dominant goal remains the driving force for change. ${ }^{71}$ It is therefore possible for a republican approach to the children of prisoners to be made immediately manifest by the adoption of aspects of innovative practices already operating within the system, such as those grounded in therapeutic jurisprudence, ${ }^{72}$ restorative justice, ${ }^{73}$ or rights-based agendas, ${ }^{74}$ as many of these practices are congruent with a republican agenda. ${ }^{75}$ Criminal justice agencies throughout Australia such as police and corrections services can take immediate steps to implement clear and consistent child-focused policies to guide processes of arrest and detention. These could, for example, be framed around the 'best interests' standards articulated in the Convention on the Rights of the Child. ${ }^{76}$ This would help to ensure that a systemic approach is articulated and that the standard of behaviour of individual officers is consistent and transparent. Well-developed child-focused frameworks already exist in other areas of the legal system, such as family law, youth justice and child protection and it would not be difficult to adapt appropriate practices from those jurisdictions. Because the theory allows for practical and incremental changes to be made at each point in the criminal justice system, there is no need to wait for major systemic change to begin implementing processes that benefit children. Criminal justice agencies and other social services can begin to implement processes immediately with the view to driving long-term change over time.

$71 \quad$ Ibid, 204.

72 See, eg, Bruce J Winick, 'The Jurisprudence of Therapeutic Jurisprudence' (1997) 3 Psychology, Public Policy and Law 184; Bruce J Winick and David B Wexler (eds) Judging in a Therapeutic Key: Therapeutic Jurisprudence and the Courts (Carolina Academic Press, 2003); Scott R Senjo and Leslie A Leip, 'Testing and Developing Theory in Drug Court: A Four-Part Logit Model to Predict Program Completion' (2001) 12(1) Criminal Justice Policy Review 66 highlight the success of drug courts that use therapeutic processes - particularly with respect to the nature of judge/offender interactions; Deborah Koetzle Shaffer, 'Looking Inside the Black Box of Drug Courts: A Meta-analytic Review' (2011) 28 Justice Quarterly 493 and Ojmarrh Mitchell, David B Wilson, Amy Eggers and Doris L MacKenzie, 'Assessing the Effectiveness of Drug Courts on Recidivism: A Meta-analytic Review of Traditional and Non-traditional Drug Courts' (2012) 40 Journal of Criminal Justice 60 demonstrate the strength of drug court processes.

73 Such as procedures used in family group or youth justice conferences processes, see eg, Allison Morris and Gabrielle Maxwell (eds) Restorative Justice for Juveniles: Conferencing, Mediation and Circles (Hart Publishing, 2001).

74 Such as embedding charters of rights into legislation and policy, for example, as currently appears in the Youth Justice Act 1992 (Qld).

75 John Braithwaite, 'Restorative Justice and Therapeutic Jurisprudence' (2002)

38(2) Criminal Law Bulletin 244, 247.

76 United Nations Convention on the Rights of the Child (CROC) (1989). 
A way to explore the potential of republican criminology with respect to children of prisoners is to revisit the case of Jessica and Bradley and to tentatively explore how this scenario would change if the actions of the state were underpinned by this theory. Jessica's children were affected by the actions of police, courts, and corrective services, as well as by the presence or absence of broader social support. If the goal of maximising the personal dominion of children were embedded as a normative framework, each agency would have developed guidelines about what to do if they came into contact with children when interacting with offenders. Importantly, this would include clear statements about the duties owed to the child and the extent of the responsibility of the agency, such as how and when responsibility is activated and discharged.

This would mean that the police officers who arrested Jessica and Bradley would have come prepared with a clear strategy about how to interact meaningfully with the children and would have formulated a draft plan to ensure that referrals could be made to address the children's care needs, had their grandmother not been available. After Jessica and Bradley were arrested, the police officers would discharge their responsibility to the children by making a timely referral to a dedicated social service to follow up with the children to explain the criminal justice process and to help the children liaise with relevant criminal justice agencies throughout the process. Perhaps the police may have also considered whether it was necessary to arrest both parents simultaneously or indeed, more ambitiously, how search and arrest processes could be carried out differently to lessen their impact on children but still succeed operationally.

Similarly, consideration of children's personal dominion would likely prompt change to court processes (and to the law that underpins these processes), and to corrective services policies. Some of these changes could be quite simple, such as changes to telephone access for prisoners and education programs to help support prisoners to communicate with their children. Others might be more substantive, such as limiting the use of remand, or the development of family-friendly prison environments or effective non-custodial sentences. Considering Jessica and Bradley's situation in this way demonstrates the transformative potential of the theory, but also highlights the tensions and practical difficulties that require further attention and careful consideration.

To support criminal justice agencies, a range of robust social services would need to be funded so that there were referral options readily available. This would also provide children with support that is appropriate to their needs. This might include services such as specialised counselling and family support, advocacy, educational support, and practical assistance to facilitate prison visits and ongoing communication with parents. Services might also support parents in building skills to engage more meaningfully with children through their term of imprisonment, as this would support the personal dominion of both parent and child into the future. 


\section{Conclusion}

If we apply a republican perspective to the situation of prisoners' children, we can see that the systemic blindness of the criminal justice system to the existence of children has the effect of diminishing their 'dominion'. The lack of attention paid to the rights and interests of children of prisoners robs them of their ability to be heard on matters that significantly affect them during the criminal justice system process. In addition, they can often be placed in positions where they are 'vulnerable to the powerful', both in terms of public institutions (such as police services, courts, and prisons), and in private spheres (at home, with family and in peer groups). If, instead, the goal of the criminal justice system was to consider how to assure the personal domain of all the relevant stakeholders affected by crime, children of prisoners can be seen in their own right instead of being obscured by the actions of their parents. It is also possible for the system to take a broader view of the needs of all the parties affected by crime, rather than focusing specifically on responding to an offender. Most important, this framework is a positive, strength-based framework that affords children respect and power over the things that happen to them.

Much work remains to be done to explore how a republican agenda can be practically embedded into criminal justice process for the benefit of children at each stage of the system. This may require a careful evaluation of current practices and the formulation of clear policies and practices, as well as further research on the support needs of children of prisoners to ensure that meaningful services are provided within and beyond the criminal justice system. In the short term, incremental change can be made within criminal justice system agencies to ensure that interventions are oriented towards the maximisation of personal dominion for the children of prisoners. In the long-term, a commitment to a republican goal has the potential to drive deep and transformative change within the criminal justice system for the benefit of all stakeholders.

\section{ACKNOWLEDGMENTS}

This research has been supported by an Australian Postgraduate Award (Industry) scholarship for the lead author as part of an Australian Research Council Linkage grant (LP0776296), an Australian Research Council Future Fellowship (FT0991557) for the second author, and by partner organisations, Queensland Corrective Services, Department of Communities, Child Safety and Disability Services, and Catholic Prison Ministry. Views expressed in this paper are those of the authors and do not necessarily represent those of the Australian Research Council or partner organisations. Where quoted or used, views should be clearly attributed to the authors. 